\title{
Sustainable land use in the Sudano-Sahelian zone of Mali: Exploring economically viable options using multiple goal linear programming.
}

\author{
E.J. BAKKER ${ }^{1 *}$, H. HENGSDIJK ${ }^{2}$ AND K. SISSOKO ${ }^{3}$
}

1. AB-DLO, P.O. Box 14, NL-6700 AA Wageningen, The Netherlands (current address: Department of Horticulture, Agricultural University, Haagsteeg 3, NL-6708 PM Wageningen The Netherlands)

2. AB-DLO, see above (actual address: Gruttoweide 81, NL-6708 BC Wageningen, The Netherlands)

3. Institut Economie Rurale, BP 258, Bamako, République du Mali

* Corresponding author (fax: +31-317-484709; e-mail: evert-jan.bakker@users.tbpt.wau.nl)

Received 1 May 1997; accepted 15 January 1998

\begin{abstract}
Technical options in crop and animal husbandry to reduce soil nutrient mining and other forms of natural resource degradation in the Sudano-Sahelian zone should be economically attractive, if they are to be adopted. A model is presented in which agronomic and economic information and goals are combined to explore possibilities for agroecologically sustainable and economically viable land use in three different climatic regions in Mali and for a situation of non-degraded soils. The time horizon of the study is the year 2010. For each region, an agroecologically sustainable land use system (a combination of crop, livestock and pasture production systems) that maximises income of the agricultural sector and satisfies self sufficiency targets is identified. Special attention is given to the use of chemical fertiliser in crop activities. It is shown that use of chemical fertiliser is an important element of sustainable and economically viable land use, especially in higher rainfall regions. It is also concluded that population size has a marked effect on optimal land use systems in the regions, but that self sufficiency is not endangered even if population is $50 \%$ higher than estimated for 2010. It is argued that results should not be used to simulate the actual situation or future developments, but to define priorities for agricultural development in the Sudano-Sahelian region.
\end{abstract}

\section{Résumé}

Pour être adoptées, les options techniques de production culturale et animale visant à réduire l'épuisement et d'autres formes de dégradation des ressources naturelles en zone sudano-sahélienne doivent être économiquement rentables. Cette étude présente un modèle de programmation linéaire à buts multiples qui combine des informations agronomiques et économiques pour analyser les possibilités d'une utilisation des terres durable (du point de vue agro-écologique) et rentable (du point de vue économique) et d'une situation de non-dégradation des terres dans trois régions climatiques du Mali. L'horizon temporel retenu est l'an 2010. Pour chaque région, un système d'utilisation des terres (une combinaison de systèmes de production agro-sylvo-pastorale), maximisant le revenue du secteur agricole tout en satisfaisant des objectifs d'autosuffisance est identifié. Une attention particulière est accordée à l'utilisation des engrais chimiques. Il est démontré qu'elle constitue un élément important d'une utilisation des terres durable et rentable, notamment dans les régions de pluviométrie élevée. Il est conclu aussi que la taille de la population aura un effet remarquant sur le système optimal d'utilisation des terres, mais que l'autosuffisance n'est pas en danger dans de tels systèmes, même avec l'hypothèse que la population serait de 50\% plus élevée que celle estimée pour l'an 2010. Il est souligné que les résultats sont à utiliser, non pas pour simuler la situation actuelle ou future, mais pour l'identification des priorités dans le développement agricole en zone Soudano-Sahélienne.

\author{
Keywords: \\ Mots clés: \\ land use analysis, fertiliser, intensification, multidisciplanary research \\ utilisation de terre, engrais chimiques, intensification, recherche multidisciplinaire
}




\section{Introduction}

Agriculture in Mali and other Sahelian countries is generally characterised by low productivity, mainly caused by low soil fertility (Penning de Vries \& Djitèye, 1982; Van Keulen \& Breman, 1990) and low and variable rainfall (Vierich \& Stoop, 1990), which results in a high level of food insecurity (Sijms, 1992). Rapid demographic growth of 3\% (Anonymus, 1995) aggravates the problem as it increases the pressure on land and finally leads to the degradation of natural resources. In cropping systems, fallow periods are shortened and soil fertility restoration through manure and chemical fertiliser is insufficient (Van Der Pol, 1992). Natural rangelands suffer from overgrazing, causing erosion, loss of perennial species and a decreasing tree population (Breman \& Traoré, 1987).

Technically speaking, some solutions are available. Van Keulen \& Breman (1990) show that higher agricultural productivity can be attained by increased use of fertilisers. These inputs also reduce soil nutrient depletion. In animal husbandry, productivity can be increased through increased use of supplementary feed, notably in the dry season, when the quality of feed from natural rangelands is low (Breman \& De Ridder, 1991). However, these alternatives have, so far, not been adopted on a large scale, due to a large number of factors, of which high cost and limited availability are the most important (Mwangi, 1997; Van Duivenbooden, 1993).

This paper presents results of an exploration of possibilities for sustainable agriculture in the Sudano-Sahelian zone of Mali. Sustainable agriculture in this context refers to a situation in which soil nutrient and organic matter stocks do not decrease, and erosion is limited. The tool used for the exploration is a multiple goal linear programming (MGLP) model, allowing to integrate quantitative agronomic and economic information, and to analyse conflicts that may exist between various development objectives (De Wit et al., 1988). It is explicitly noted that the methodology used aims at exploring options for sustainable agriculture, not at predicting or prescribing agricultural development. Results indicate technical possibilities in relation to explicitly defined objectives. As technical possibilities and socio-economic or political goals are separated in explorative studies, their results may help to better prioritise the discussion about development, and hence make them more meaningful. Exploration is not concerned with actual applicability but with identification of possibilities for technological change (Van Ittersum et al., submitted). In the present case this means that the actual degree of soil degradation is not taken into account, as it is regarded as a problem that could be overcome through soil amelioration programs.

The aim of the paper is to show that sustainable and economically viable agriculture in the Sudano-Sahelian zone is possible that could guarantee food self-sufficiency in the year 2010 for different population growth scenarios, and to indicate what (type of) cropping-, animal husbandry-, wood production -and pasture systems would be selected as components of such a sustainable agricultural system. This is done for three climatic regions in Mali. Special attention is paid to the role of inorganic fertiliser.

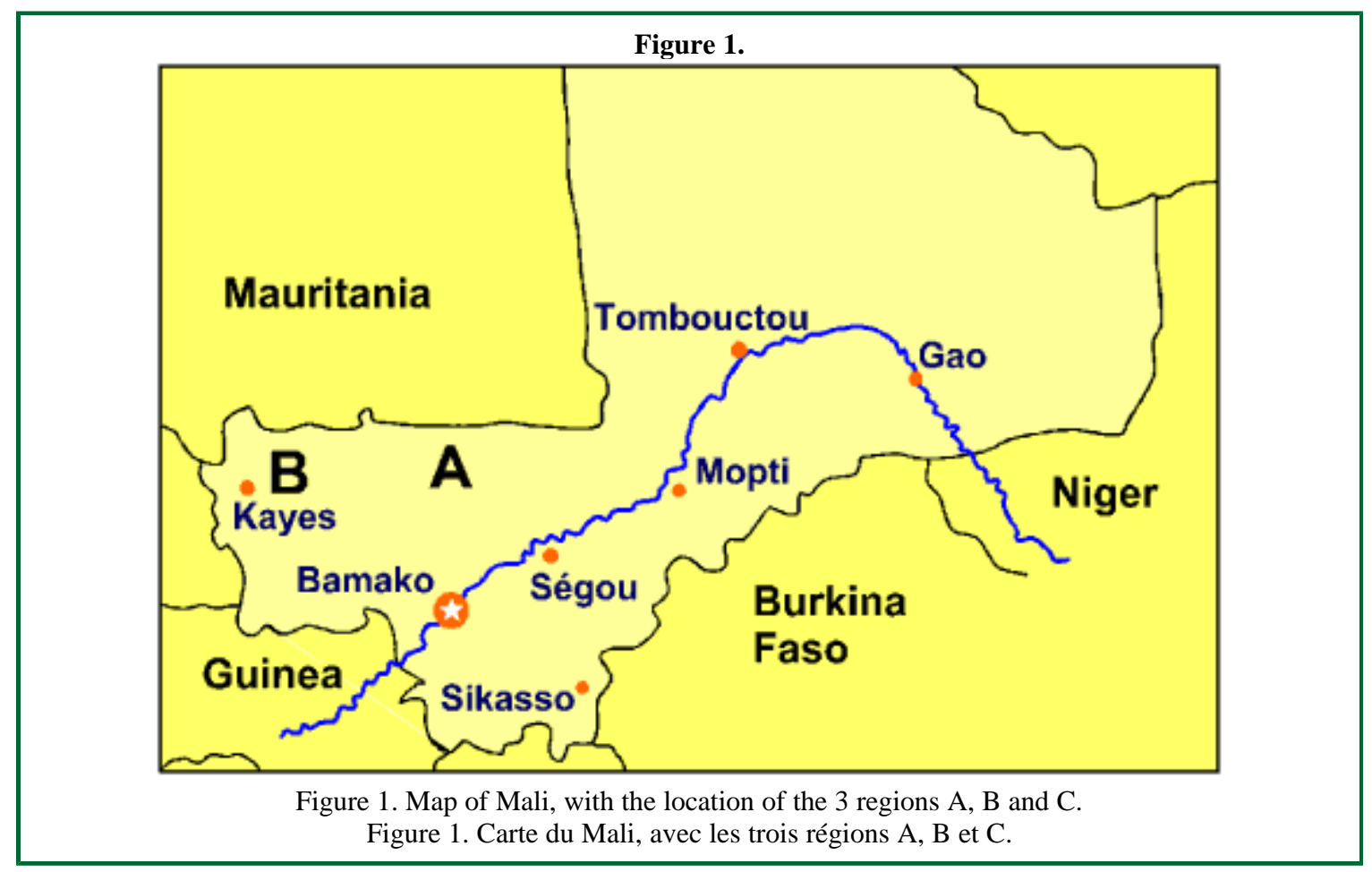




\section{Materials and methods}

For this study three regions in the Sudano-Sahelian zone of Mali are chosen such that they represent three climatic zones in West Africa (Figure 1). Region A (north of Bamako) represents the north Sahelian zone, region B (in Kayes) the south Sahelian zone, and region C (north of Sikasso) the Sudanian zone. The regions are characterised briefly in Table 1 and described in more detail in Quak et al. (1996). Table 1 indicates that population and animal densities increase and soils tend to be heavier in regions with higher rainfall. Estimation of population density per region in the year 2010 is based on the census data for 1987 and 1976 (Anonymus, 1991), on the basis of which it was also possible to calculate annual growth rates per region, making a distinction between rural and urban population. Calculated growth rates for the 3 regions varied between 1.8 and $2.1 \%$. In the base model $2 \%$, is used for the three regions. This is considerably lower than the actual average for Mali as a whole (3\%), but close to that for the rural population, which is $2.3 \%$ (Anonymus, 1993). Consequences of other population growth scenarios will be discussed. Labour availability depends on population and its active proportion. It is estimated at $55 \%$ on the basis of age distribution and data presented by Veeneklaas et al. (1991).

Table 1. Descriptive statistics for the three study regions.

Tableau 1. Données statistiques descriptives des trois régions d'étude.

\begin{tabular}{|c|c|c|c|c|}
\hline & & \multicolumn{3}{|c|}{ Region } \\
\hline & & A & B & $\mathrm{C}$ \\
\hline Annual rainfall & $(\mathrm{mm})$ & 400 & 600 & 850 \\
\hline Area & $\left(10^{3} \mathrm{~km}^{2}\right)$ & 25.8 & 24.6 & 14.7 \\
\hline Population density in $2010^{1)}$ & $\left(\right.$ no. $\mathrm{km}^{-2}$ ) & 8 & 20 & 42 \\
\hline Animal density in 1992 2) & $\left(\mathrm{TLU} \mathrm{km} \mathrm{km}^{-2}\right)$ & 3 & 7 & 19 \\
\hline Land resources by soil type & $(\%)$ & & & \\
\hline$\square$ Clay depressions & & 1 & 8 & 5 \\
\hline$\square$ Clayey loam & & 0 & 7 & 23 \\
\hline$\square$ Loam & & 3 & 23 & 11 \\
\hline$\square$ Sandy Loam & & 54 & 21 & 3 \\
\hline$\square$ Loamy Sand & & 36 & 0 & 0 \\
\hline$\square$ Sand & & 0 & 0 & 0 \\
\hline$\square$ Gravely & & 6 & 22 & 25 \\
\hline$\square$ Unfit for crops & & 0 & 19 & 32 \\
\hline
\end{tabular}

The model used is a regional MGLP model of the agricultural sector, based on Veeneklaas (1990). It is described in detail in Bakker et al. (1996b). It comprises quantified descriptions of land use activities on a hectare basis, a set of technical constraints and a number of objectives. In a single model run, any objective can be optimised on its own, while minimum or maximum target values for other objectives can be specified in goal constraints. The choice of the objective to be optimised and the target values for the other objectives depend on the user's specific aims and interests. Objectives considered in this study are production of cereals, cotton, meat, milk, wood in an "averagerainfall" year, cereal production in a dry year, and financial objectives (regional net revenue, production value) expressed in the local currency (FCFA). Technical constraints are included to represent limitations like land and labour availability, and e.g. the fact that animals can not eat more feed than is produced. Model results include the allocation of resources to different land use activities and values for the objectives, thus showing the consequences of a combination of objectives and goal constraints.

The major types of land use in the model are arable cropping, livestock husbandry, use of rangeland, plantation wood production and fallowing. For each of these land use types a number of activities has been defined and characterised by quantified output (production of main and by products) and input (land, labour, straw, nutrients, etc.) per hectare or per TLU (tropical livestock unit, an animal of $250 \mathrm{~kg}$ live weight). Quantification, of which details are given by Quak et al. (1996) and Bakker et al. (1996a), is based on the integration of different types of standard data (climate and soil characteristics, labour task times, etc.), models (relation between feed intake and animal growth, crop growth simulation models), and expert knowledge, following a target-oriented approach (Van 
Ittersum \& Rabbinge, 1997). Four production levels are defined and for each of these levels necessary inputs are determined. The highest crop production level is still considerably lower than calculated water limited yield to account for harvest and post- harvest losses (Van Duivenbooden \& Veeneklaas, 1993). Land use activities are quantified for a situation of non-degraded soils, so that model results also refer to such a non-degraded situation. The costs of maintaining soil organic matter, nitrogen, phosphorus and potassium stocks are included in the model, but not the costs of soil amelioration. For cropping and rangeland activities, inputs and outputs are calculated for an average rainfall year as well for a dry year. Average rainfall (quantity and distribution per 10 day period) is based on 30 years of rainfall data of two to five meteorological stations per region. Calculation of rainfall in a dry year is based on the $20 \%$ lowest rainfall years of the monitoring period.

Main products are valued at their prices and contribute directly to financial goals in the model. Based on average farm gate prices for the period 1989-1993 (Anonymus, 1994), the following prices (FCFA kg ${ }^{-1}$ ) are used: 50 for cereals, 75 for legume crops, 125 for cotton, 340 for meat (live weight), and 150 for milk. Construction wood and burning wood, are valued at 3000 and 1500 FCFA m$^{-3}$, respectively. Net revenue is defined as added value: production value minus cost of consumed inputs and depreciation of equipment. It represents the compensation of the use of the production factors land, labour and capital. Intermediate products, such as manure and crop residues, are not valued, but can be exchanged among land use activities in the MGLP-model, thus allowing the integration of crop and animal activities.

Results are presented for a number of model runs. First, the so-called playing field is determined: maximum values for each of the objectives separately. These values are calculated in model runs with no requirements for any other objective than the one maximised. In the next model run, the base run, net revenue is maximised, subject to self- sufficiency requirements. Self sufficiency targets, expressed per inhabitant and per year, are defined for a number of products in an average rainfall year: cereals $(240 \mathrm{~kg})$, milk $(40 \mathrm{~kg})$, meat $(18 \mathrm{~kg}$ live weight, which is equivalent to $9 \mathrm{~kg}$ of meat), construction wood $\left(0.17 \mathrm{~m}^{3}\right)$ and burning wood $\left(0.75 \mathrm{~m}^{3}\right)$. Cereal requirements in a dry year are $216 \mathrm{~kg}$ per inhabitant, while the other requirements remain the same. Finally, results are presented of sensitivity analyses for

i. limited availability of fertiliser and

ii. alternative population growth scenarios.

\section{Results and discussion}

\section{Playing field}

Table 2. The playing field: maximum values per year for the objectives in three regions, expressed per hectare of total area and per inhabitant.

Tableau 2. Le terrain de jeu: valeurs maximales pour des objectives en trois régions exprimé par hectare de superficie totale et par habitant.

\begin{tabular}{|c|c|c|c|c|c|c|c|}
\hline \multirow[b]{3}{*}{ Objective } & \multirow[b]{3}{*}{ Unit } & \multicolumn{3}{|c|}{ Per hectare } & \multicolumn{3}{|c|}{ Per inhabitant } \\
\hline & & \multicolumn{3}{|c|}{ Region } & \multicolumn{3}{|c|}{ Region } \\
\hline & & A & B & $\mathrm{C}$ & A & B & $\mathrm{C}$ \\
\hline Net revenue & $10^{3}$ FCFA & 7 & 24 & 53 & 95 & 119 & 128 \\
\hline Production value & $10^{3}$ FCFA & 9 & 37 & 87 & 119 & 185 & 210 \\
\hline Cereals & $\mathrm{kg}$ & 57 & 351 & 1.326 & 728 & 1.735 & 3.181 \\
\hline Cotton & $\mathrm{kg}$ & 0 & 59 & 268 & 0 & 294 & 644 \\
\hline Milk & $\mathrm{kg}$ & 28 & 119 & 170 & 357 & 587 & 407 \\
\hline Live weight & $\mathrm{kg}$ & 10 & 44 & 65 & 127 & 219 & 157 \\
\hline Construction wood & $\mathrm{m}^{3}$ & 0.32 & 0.93 & 1.18 & 4.1 & 4.6 & 2.8 \\
\hline
\end{tabular}

The playing field for the regions A, B and C is given in Table 2 . To facilitate comparison among regions results are expressed per unit of total area and per inhabitant. Self-sufficiency targets as defined in the previous section can be 
satisfied, when considered separately. Table $\underline{2}$ does not give information about the values of the objectives that can be simultaneously realised.

As expected, land productivity increases with rainfall, i.e maximum values of the objectives per hectare in zone $\mathrm{C}$ are higher than in zones B and A. This also holds for most of the objective values per inhabitant, but to a lesser extent as population density also increases with rainfall. Maximum net revenue values per inhabitant do not differ much between the three regions. Relative differences among regions are less pronounced in animal production than in crop production. Expressed per inhabitant, objective values for region $\mathrm{C}$ are even lower than for region $\mathrm{B}$. These results indicate that, as in actual practice, also in the situation in which land use is sustainable, drier regions have a comparative advantage for animal production, and wetter regions for crop production.

\section{Net revenue maximisation and self sufficiency requirements}

In the base run, self-sufficiency targets for cereals, milk, meat and wood are minimally required, while net revenue is the objective maximised. In Table $\underline{3}$ values for net revenue and the other objectives are given. The production of construction wood is exactly at the required self-sufficiency level, while attained values for the other production goals are higher than those required. This implies that in none of the three regions self-sufficiency constraints are conflicting with the net revenue objective, except those for construction wood. The results therefore suggest that agro- ecologically sustainable arable cropping and animal production can be integrated in the Sudano-Sahelian zone, such that self-sufficiency requirements for the year 2010 are met, if the required investments in soil fertility have been made.

Table 3. Base run model results for three regions: values for the objective variables, expressed per hectare of total area and per inhabitant.

Tableau 3. Résultats du modèle de base pour trois régions: valeurs des variables objectifs, exprimé par hectare de superficie totale et par habitant.

\begin{tabular}{|c|c|c|c|c|c|c|c|}
\hline \multirow[b]{3}{*}{ Objective } & \multirow[b]{3}{*}{ Unit } & \multicolumn{3}{|c|}{ Per hectare } & \multicolumn{3}{|c|}{ Per inhabitant } \\
\hline & & \multicolumn{3}{|c|}{ Region } & \multicolumn{3}{|c|}{ Region } \\
\hline & & A & B & $\mathrm{C}$ & A & B & $\mathrm{C}$ \\
\hline Net revenue & $10^{3}$ FCFA & 7 & 23 & 52 & 89 & 115 & 125 \\
\hline Production value & $10^{3}$ FCFA & 9 & 31 & 82 & 110 & 154 & 196 \\
\hline Cereals & $\mathrm{kg}$ & 35 & 272 & 940 & 454 & 1,346 & 2,255 \\
\hline Cotton & $\mathrm{kg}$ & 0 & 0 & 17 & 0 & 0 & 41 \\
\hline Milk & $\mathrm{kg}$ & 26 & 63 & 112 & 329 & 311 & 269 \\
\hline Live weight & $\mathrm{kg}$ & 8 & 21 & 42 & 108 & 105 & 100 \\
\hline Construction wood & $\mathrm{m}^{3}$ & 0.13 & 0.34 & 0.71 & 0.17 & 0.17 & 0.17 \\
\hline
\end{tabular}

As in the playing field, net revenue per hectare in region $\mathrm{C}$ is higher than in regions $\mathrm{B}$ and $\mathrm{A}$, and, to a lesser extent, this also holds for net revenue per inhabitant, again because of differences in population density. The revenues per inhabitant compare favourably with actual per capita income in Mali, which is around 140,000 FCFA, of which 44\% (or 61,000 FCFA) come from agriculture (Anonymus, 1995).

The results indicate therefore that sustainable agriculture can not only guarantee self- sufficiency but is also economically viable. To demonstrate the robustness of this conclusion for other demographic growth scenarios, sensitivity analyses are presented in the section on population density.

Labour use varies from period to period. For the three regions, labour is fully used in one or a few peak periods (Table 4), the most important of which is at the time of first weeding. Average labour use, calculated as the ratio of the use and the availability of labour, both expressed in man-years, is lower in region C than in B and A. Available labour that is not used can be seen as an indicator for unemployment. Since results show a maximum average labour use of $51 \%$, they indicate a big need and opportunity for non-agricultural employment, especially in the offseason, which has also been demonstrated by Van Duivenbooden (1993). Two measures for labour productivity are presented in Table $\underline{4}$ : productivity of available labour, calculated as net revenue divided by labour availability, and productivity of labour used, calculated as the ratio of net revenue and total labour input (in man-years). In region $\mathrm{C}$ average productivity of labour used is around 2,100 FCFA per man-day, which is high compared to figures that are found for a zone inside of region C (Diallo et al., 1992), which vary from 460 to 900 FCFA per man-day. 
Table 4. Base run model results for three regions: distribution of land use, labour use, crop yields and fertiliser use.

Tableau 4. Résultats du modèle de base pour trois régions: utilisation de terre, de main d'oeuvre, et des engrais chimiques et les rendement de culture.

\begin{tabular}{|c|c|c|c|c|}
\hline & \multirow[b]{2}{*}{ Unit } & \multicolumn{3}{|c|}{ Region } \\
\hline & & A & $\mathrm{B}$ & $\mathrm{C}$ \\
\hline Land use: & $\%$ & & & \\
\hline$\square$ Crops & & 2 & 8 & 21 \\
\hline$\square$ Fallow & & 25 & 0 & 0 \\
\hline$\square$ Rangeland & & 72 & 90 & 77 \\
\hline$\square$ Wood plantation & & 1 & 1 & 2 \\
\hline Average labour use & $\%$ & 51 & 47 & 35 \\
\hline Labour use in peak period & $\%$ & 100 & 100 & 100 \\
\hline Net revenue per man-year available & FCFA & 162 & 210 & 227 \\
\hline Net revenue per man-year worked & FCFA & 317 & 447 & 648 \\
\hline Average crop yields: & $\mathrm{tha}^{-1}$ & & & \\
\hline$\square$ Cereals & & 1.5 & 4.3 & 6.0 \\
\hline$\square$ Cotton & & - & - & 2.0 \\
\hline $\begin{array}{l}\text { Fertilizer element use in crop } \\
\text { cultivation: }\end{array}$ & $\mathrm{kg} \mathrm{ha}^{-1}$ & & & \\
\hline$\square$ Nitrogen & & 27 & 81 & 88 \\
\hline$\square$ Phosphorus & & 0 & 0 & 43 \\
\hline$\square$ Potassium & & 0 & 15 & 57 \\
\hline
\end{tabular}

Some characteristics of the calculated distribution of land use are presented in Table $\underline{4}$. They show that in all regions rangelands is by far the most important type of land use. Wood plantations occupy the minimum area needed to supply the self-sufficiency target for construction wood. Cropped area increases with increasing rainfall and increasing man-land ratio, which is proportional to population density (see Table 1), but even for region C rangeland covers $77 \%$ of the total area. Fallowing to maintain soil organic matter and nutrient stocks is an option only used in region A, as a consequence of labour shortage in peak periods, as can be seen in the sequel from the results on variation in population (see section on Population density). In the other regions other measures to maintain soil organic matter and nutrient stocks are economically more attractive. Cropping activities selected by the model are characterised by high production levels and, in order to guarantee sustainability, relatively high fertiliser use. N-fertilisation rates vary between 27 and $88 \mathrm{~kg} \mathrm{ha}^{-1}$ among regions, while actual (nitrogen) fertiliser use in Mali is estimated at $7 \mathrm{~kg}$ of nutrient element per ha of arable land (Mwangi, 1997; Van Duivenbooden, 1993).

In Table $\underline{5}$ some results on animal production are presented. Calculated animal densities, expressed in TLU (tropical livestock unit, representing $250 \mathrm{~kg}$ live weight), are much higher than current densities (Table 1). The main reason that more animals could be present in an actually overgrazed situation is the improved feed situation. In region $\mathrm{C}$ this is the result of the use of cereal straw and the production of fodder crops which supply all the feed in the dry season. Feed production from rangelands is completely used in the rainy season. In region A the increased animal density can be maintained on the basis of the rangeland productivity, which is higher than in the current situation. This is caused by the fact that in the current situation rangelands are degraded, while in the calculations soils are supposed to be in an optimal production situation, given soil type and climate. Moreover, long term productivity is maximised using an optimal grazing strategy which prevents overgrazing. Selected animal production systems are in the highest two of four productivity categories, indicating that more intensive animal husbandry systems use available feed more efficiently. 
Table 5. Base run results for three regions: animal productivity, animal density, and feed resources in the dry season.

Tableau 5. Résultats du modèle de base pour trois régions: productivité et densité animale, et sources fourragères pendant la saison sèche.

\section{Unit}

\begin{tabular}{|l|c|c|}
\hline \multicolumn{3}{|c|}{ Region } \\
\hline A & B & C \\
\hline
\end{tabular}

\section{Productivity}

\begin{tabular}{|c|c|c|c|c|}
\hline$\square$ milk & $\mathrm{kg} \mathrm{TLU}^{-1} \mathrm{yr}^{-1}$ & 228 & 217 & 232 \\
\hline$\square$ live weight & $\mathrm{kg} \mathrm{TLU}^{-1} \mathrm{yr}^{-1}$ & 75 & 73 & 86 \\
\hline Animal density & TLU km ${ }^{-2}$ & 11 & 29 & 48 \\
\hline Animals used for traction & $\%$ of total & 8 & 11 & 10 \\
\hline Feed availability, dry season & $(\%)$ & & & \\
\hline$\square$ feed from rangelands & & 98 & 35 & 0 \\
\hline$\square$ cereal residues & & 2 & 62 & 90 \\
\hline$\square$ legume leaves & & 0 & 1 & 0 \\
\hline$\square$ fodder crops & & 0 & 2 & 10 \\
\hline
\end{tabular}

\section{Fertiliser availability}

In linear programming, the solution (allocation of land to various activities) can be very sensitive to changes in one or more coefficients, while the value of the objective function is not. This implies that if e.g. much less fertiliser were available than the quantities given in Table $\underline{4}$, regional net revenue would only be slightly lower. To investigate the effect of fertiliser availability, several model runs were made in which fertiliser availability was limited. This was done by including a restriction of the following form: FE $\leq$ fraction * FEo, where FE and FEo are the fertiliser expenses in the actual model and in the base run, respectively. The fraction was varied from 0 to 1 in steps of 0.1 .
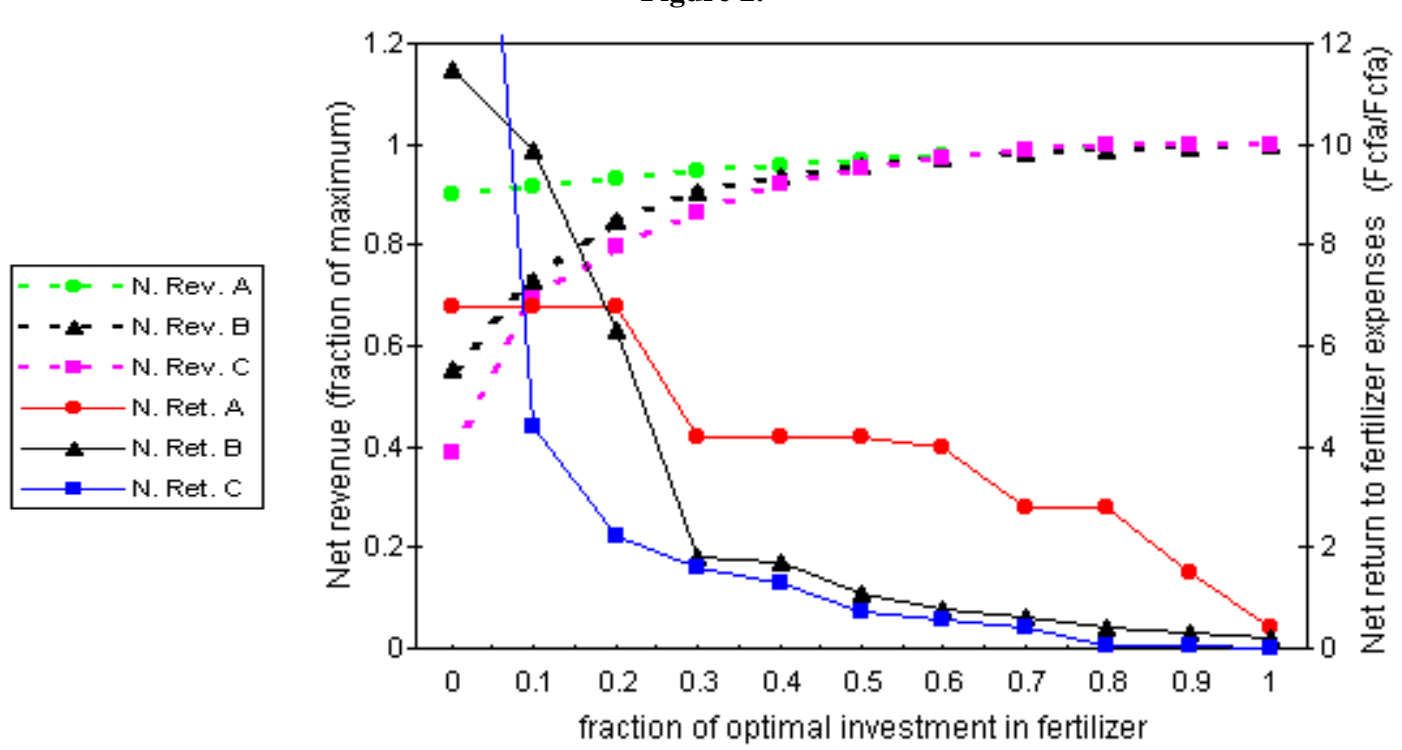

Figure 2. Net return to investment in fertilizer (as a fraction of calculated "optimal" investment) and its effect on regional net revenue (as a fraction of maximum net revenue).

Figure 2. Valeur marginale d'investissement en angrais chimiques (exprimé comme fraction de l'investissement optimal calculé) et son effet sur le revenue régional (fraction du revenue maximum).

In Figure $\underline{2}$ two types of results are presented. The first is the effect of the constraint on the objective function (net revenue). In region $\mathrm{C}$, for example, using only $50 \%$ of the fertiliser used in the base run, would lead to a reduction of only $5 \%$ in net revenue, whereas a complete lack of fertiliser would lead to a $60 \%$ reduction. The second type of 
result presented in Figure $\underline{2}$ represents the opportunity cost of the fertiliser restriction or the (decreasing) marginal returns to fertiliser expenses. At the point with zero fertiliser use, the first fertiliser expenses in region $\mathrm{C}$ would have a net return of 24 FCFA per FCFA spent on fertiliser (point outside the graph), in region A 7 FCFA FCFA ${ }^{-1}$. For regions $\mathrm{B}$ and $\mathrm{C}$ net returns drop below $1 \mathrm{FCFA} \mathrm{FCFA}^{-1}$ at around $50 \%$ of fertiliser expenses calculated in the base run. In practice, higher investment in fertiliser would probably stop because of the risk involved in fertiliser expenses. The cut-off point varies in practice between individual farmers. If fertiliser expenses would be $40 \%$ of the calculated optimum, net revenue in regions $\mathrm{B}$ and $\mathrm{C}$ would be $8 \%$ lower than the calculated maximum, while in region $\mathrm{A}$, where fertiliser plays a less important role, net return to fertiliser expenses remains at a relatively high level up to over $80 \%$ of the calculated optimal investment.

\section{Population density}

To examine the effect of population size on possibilities for agro-ecologically sustainable land use, optimisation runs were carried out for population sizes of $60 \%$ and $150 \%$ of that in the base run. The size of the regional population influences model results in two ways. First, self-sufficiency requirements are more difficult to meet when the population is larger, as self-sufficiency targets are proportional to population size. In this case, a proportional increase in the production of construction wood and, as a consequence in its use of land (Table $\underline{6}$ ), has a negative impact on net revenue. The second effect of a population increase is an increase of labour availability. To what extent this influences maximum net revenue depends on marginal labour productivity. Table $\underline{6}$ shows that there are marked differences among regions. A population of $60 \%$ of that in the base run results in a net revenue per inhabitant in region $\mathrm{A}$ that is only $4 \%$ higher than in the base run, while in region $\mathrm{C}$ this is $31 \%$, and in region $\mathrm{B}$ $39 \%$. In regions $\mathrm{B}$ and $\mathrm{C}$, therefore, productivity of available labour decreases considerably when population increases, indicating a stronger relative land shortage than in region A. With $50 \%$ more population than in the base run revenues per inhabitant drop by $13 \%$ in region $\mathrm{A}$, and by $20-21 \%$ in regions $\mathrm{B}$ and $\mathrm{C}$.

Table 6. Effects of population densities of 60 and $150 \%$ of base run density on base run results (\%).

Tableau 6. Effets des densités de population de 60 et $150 \%$ de celle du run de base aux résultats (\%).

\begin{tabular}{|c|c|c|c|c|c|c|}
\hline & \multirow{2}{*}{\multicolumn{2}{|c|}{$\begin{array}{l}\text { Region A } \\
\text { population }\end{array}$}} & \multirow{2}{*}{\multicolumn{2}{|c|}{$\begin{array}{l}\text { Region B } \\
\text { population }\end{array}$}} & \multirow{2}{*}{\multicolumn{2}{|c|}{$\begin{array}{l}\text { Region C } \\
\text { population }\end{array}$}} \\
\hline & & & & & & \\
\hline & $60 \%$ & $150 \%$ & $60 \%$ & $150 \%$ & $60 \%$ & $150 \%$ \\
\hline Net revenue & 63 & 131 & 83 & 119 & 78 & 121 \\
\hline Net revenue per inhabitant & 104 & 87 & 139 & 79 & 131 & 80 \\
\hline \multicolumn{7}{|l|}{ Land use } \\
\hline$\square$ Wood plantation area & 60 & 150 & 60 & 150 & 60 & 150 \\
\hline$\square$ Cultivated area & 61 & 149 & 57 & 188 & 90 & 107 \\
\hline$\square$ Rangeland area & 110 & 132 & 105 & 91 & 104 & 97 \\
\hline$\square$ Fallow area & 76 & 2 & - & - & - & - \\
\hline \multicolumn{7}{|l|}{ Production } \\
\hline$\square$ Cereal production & 60 & 141 & 55 & 145 & 49 & 122 \\
\hline$\square$ Cotton production & - & - & - & - & 0 & 564 \\
\hline$\square$ Animal density & 61 & 134 & 90 & 112 & 107 & 100 \\
\hline
\end{tabular}

Effects on land use other than wood plantations differ considerably per region. In region A, the arable cropping area is almost proportionally related to labour availability, in region $\mathrm{B}$ even stronger than proportionally. In region $\mathrm{C}$ labour availability also has a positive effect on the arable cropping area, but much less pronounced. Within the arable cropping area of region $\mathrm{C}$, however, there is a shift in land use. The areas under cotton and cereals increase when population increases. Cotton area increases by more than a factor five. Cotton and cereals become more important at the expense of fodder crops when population increases to $150 \%$. Crop yields are hardly affected in any of the three regions, indicating that the productivity levels of the land use activities in the optimal solution do not change. The same holds for animal productivity: in each population growth scenario only animal production activities with the highest production levels are selected.

\section{Concluding remarks}

The agricultural sector MGLP model used is an efficient tool to integrate agro-ecological and socio-economic 
information and to explore possibilities for agro- ecologically sustainable agriculture. For interpretation of the results it is important to understand that the aim of the study is to explore the technical possibilities of sustainable agricultural land use in terms of self-sufficiency and economic viability, if soils would be in good condition. It should not and can not be used to explain or describe actual agricultural land use nor to predict its future development. Several limitations apply, for example the model treats each region as one big super-farm in stead of a collection of different farms, transport costs of inputs and outputs are not accounted for, and the linearity of the model does not allow to integrate economies of scale. Another important assumption underlying the model is that of non-degraded soils, which does not reflect the current situation.

Results indicate that, under the assumptions made, agro-ecologically sustainable agriculture is possible and can satisfy self-sufficiency requirements for the estimated population in the year 2010, for different population growth scenarios, and even in dry years. Such an agriculture would also be economically viable. Even in the $440 \mathrm{~mm}$. rainfall region $\mathrm{A}$, and with a much higher than actual population density, income from agriculture per inhabitant would be higher than the actual average for Mali. In regions B and C income figures are higher. These results are obtained with relatively low prices, but also with the assumption that all surplus production can be marketed.

In regions $\mathrm{B}$ and $\mathrm{C}$ insufficient land for agricultural production is available to maintain labour productivity with increasing population growth, while in region A abundant land is available to absorb extra labour. For all three regions the model indicates full labour use in peak seasons but relatively low average labour use, which underlines the need for alternative employment, especially in the off-season.

Changes in population density affect the results in a number of ways, but some general trends are visible. A larger population and hence higher labour availability is associated with a larger cropped area, with higher regional income, but with lower income per inhabitant. The magnitude of these changes varies among regions.

Land use in all regions is dominated by rangeland, but arable cropping systems become more important as rainfall and population density increase. In all three regions fertilisers are required to attain maximum net revenues, but to a different degree. In region $\mathrm{C}$ ( $850 \mathrm{~mm}$ annual rainfall) complete absence of fertilisers would reduce regional net revenue by $60 \%$. The selected cropping systems are characterised by high yields and fertiliser use in compartison to the current situation. The same holds for animal production systems in terms of meat and milk production per TLU or per animal, which require more feed of a better quality. It seems appropriate to test the selected production techniques on station and on farm in combination with soil fertility management strategies to maintain soil nutrient stocks. In that way scientific and indigenous knowledge can be integrated with the aim to increase agricultural output in a sustainable way.

Undoubtedly, the large gap between actual and the presented sustainable agricultural land use will not be bridged overnight. Besides testing, implementation of sustainable land use activities will require a large number of accompanying measures to stimulate farmers to adopt them. Examples are regulations with respect to property rights, without which the grazing systems selected in the model cannot be applied, and modifications in the market and institutional environment that allow farmers to sell surpluses, buy fertilizer and borrow money. Which measures to implement, and how, is a subject beyond this study. The approach presented by Bade et al. (1997) seems a promising method to tackle this type of research issues.

\section{References}

\section{Anonymus, 1991.}

Récensement général de la population et de l' habitat. Direction Nationale des Statistiques et des Informations (DNSI), Bamako, 126 pp.

Anonymus 1993.

Computerized information series. Statistics 2, Population, Vol.1, Agrostat -PC.

Food and Agricultural Organisation (FAO), Rome.

Anonymus, 1994.

Données de base de 1989 à 1993.

Office des Produits Agricoles et des Marchés (OPAM)/ Systèmes des Informations et des Marchés céréaliers (SIM), Bamako.

Anonymus, 1995.

Programme de la coopération Mali-Banque Mondiale (1994).

World Bank, Washington, 93 pp.

Bade, J., H. Hengsdijk, G. Kruseman, R. Ruben \& P. Roebeling, 1997.

Farm household modelling in a regional setting: The case of Cercle de Koutiala, Mali. 
DLV-Report no. 6, Research Institute for Agrobiology and Soil Fertility (AB-DLO)/ Agricultural University Wageningen (WAU)/Landbouw Economisch Instituut (LEI-DLO), Wageningen 39 pp. 
Bakker, E.J., H. Hengsdijk, \& J.J.M.H. Ketelaars, 1996a.

Description quantitative des systèmes de production animale en zone Soudano-Sahélienne.

Rapport PSS 27, Institut d'Economie Rurale (IER)/ Research Institute for Agrobiology and Soil Fertility (AB-DLO)/ Terrestrial Ecology and Nature Conservation, Wageningen Agricultural University, (TENCWAU), Wageningen $36 \mathrm{pp}$.

Bakker, E.J., T. Van Rheenen, M.S.M. Touré, K.Sissoko, M.K. Van Ittersum \& N. De Ridder, $1996 b$. Analyse de l'utilisation de terre à l'aide de la programmation linéaire à buts multiples. Manuel de cours. Rapport PSS 30, Institut d'Economie Rurale (IER)/Research Institute for Agrobiology and Soil Fertility (ABDLO)/ Terrestrial Ecology and Nature Conservation, Wageningen Agricultural University, (TENC-WAU), Wageningen, $150 \mathrm{pp}$.

Breman, H. \& N. Traoré (Eds.), 1987.

Analyse des conditions de l'élevage et propositions de politiques et de programmes, Mali, SAHEL D(87)302. Organisation de la Coopération et de Développement Economique (OCDE, Paris)/Comité Interétat de Lutte contre la Sécheresse au Sahel (CILLS, Ouagadougou)/ Club du Sahel (Paris), Paris, 243 pp.

Breman, H. \& N. De Ridder, 1991.

Manuel sur les paturages des pays saheliens.

ACCT (l'Agence de Coopération Culturelle et Technique, Paris)-CTA (le Centre Technique de coopération Agricole et rurale, Ede/Wageningen)-Karthala, Paris, 481 pp.

De Wit, C.T, H. Van Keulen, N.G. Seligman \& I Spharim, 1988.

Application of interactive multiple goal linear programming techniques for analysis and planning of regional agricultural development. Agricultural Systems 26: 211-230.

Diallo, S., M. Kooijman, H. Djouara \& Y. Koné, 1992.

Les pratiques culturales des principales cultures dans les zones d'interventions du Département de Recherche des Systèmes de Production Rurale (DRSPR)-Sikasso. Rapport de recherche DRSPR-Sikasso/ Institut d'Economie Rurale (IER) /Mali, 22 pp.

Mwangi, W.M., 1997.

Low use of fertilizers and low productivity in sub-Saharan Africa.

Nutrient cycling in Agroecosystems 47: 135-147.

Penning De Vries, F.W.T. \& M.A. Djitèye (Eds.), 1982.

La productivité des paturages sahéliens. Une étude des sols, des végétations et de l'exploitation de cette resource naturelle.

Agricultural Research Reports 918, Pudoc, Wageningen, 525 pp.

Quak, W., H. Hengsdijk, E.J. Bakker, K. Sissoko \& M.S.M Touré, 1996.

Description agronomique quantitative des systèmes végétales en zone soudano-sahélienne.

Rapport PSS 28, Institut d'Economie Rurale (IER) /Research Institute for Agrobiology and Soil Fertility

(AB-DLO)/ Terrestrial Ecology and Nature Conservation, Wageningen Agricultural University, (TENCWAU), Wageningen, $112 \mathrm{pp}$.

Sijms, J., 1992.

Food security and policy interventions in Mali.

Tinbergen Institute, Erasmus University of Rotterdam, The Netherlands, 231pp.

Van Der Pol, F., 1992.

Soil mining. An unseen contributor to farm income in southern Mali.

Bulletin no. 325, Royal Tropical Institute, Amsterdam, 47 pp.

Van Duivenbooden, N., 1993.

Impact of inorganic fertilizer availability on land use and agricultural production in the Fifth region of Mali.

II: Scenario definition and results.

Fertilizer research 35: 1205-216.

Van Duivenbooden, N. \& F.R. Veeneklaas, 1993.

Impact of inorganic fertilizer availability on land use and agricultural production in the Fifth region of Mali.

I: Methodology and basic data.

Fertilizer research 35: 193-204.

Van Ittersum, M.K. \& R. Rabbinge, 1997.

Concepts in production ecology for analysis and quantification of agricultural input-output combinations.

Field Crops Research 52: 197-208.

Van Ittersum, M.K, R. Rabbinge \& H.C. Van Latesteijn.

Explorative land use studies and their role in strategic policy making (submitted).

Van Keulen H. \& H. Breman, 1990.

Agricultural development in the Western African Sahelian region: a cure against land hunger?

Agriculture, Ecosystems and Environment 32: 177-197. 
Veeneklaas, F.R., 1990.

Competing for limited resources: the case of the Fifth region of Mali. Report 3: Formal description of the optimisation model.

Research Centre for Agrobiology (CABO)/Etudes sur les systèmes de Productions Rurales en 5ème Région, Mopti (ESPR), CABO, Wageningen, $180 \mathrm{pp}$.

Veeneklaas, F.R., S. Cissé, PA Gossèye, N. Van Duivenbooden \& H. Van Keulen, 1991.

Competing for limited resources: the case of the Fifth region of Mali. Report 4: Development scenarios.

Research Centre for Agrobiology (CABO)/Etudes sur les systèmes de Productions Rurales en 5ème Région, Mopti (ESPR), CABO, Wageningen, $180 \mathrm{pp}$.

Vierich, H.I.D. \& W.A. Stoop, 1990.

Changes in West African savanna agriculture in response to growing population and continuing low rainfall.

Agriculture, Ecosystems and Environment 31: 115-132.

\section{Acknowledgements}

The authors wish to thank the Projet Production Sudano Sahélienne (PSS) of the Institut d'Economie Rurale (IER), Mali, the Research Institute for Agrobiology and Soil Fertility (AB-DLO) and the department of Terrestrial Ecology and Nature Conservation, Wageningen Agricultural University, (TENC-WAU), the Netherlands, for facilitating the research presented in this paper. Useful comments on an earlier version by $\mathrm{H}$. Van Keulen (Wageningen Agricultural University), N. Van Duivenbooden (Sahelian Center of the International Crops Research Institute for the Semi-Arid Tropics) and an anonymous referee are gratefully acknowledged.

C NJAS 585, 1998 - Comments to: J.J.Neetson@AB.DLO.NL 